\title{
POETRY
}

\section{The poor historian}

Previously published at www.cmaj.ca

The indigents were placed in open wards, thirty-two beds, beneath a maze of rods and drapes that slid, if they weren't ignored, to make private spaces, or the façade of them. Men on the first floor; women above. Their heads at the wall, their feet adjacent to the aisle. An umbrous gallery of portraits on the walls. The complaisant noblesse oblige of it all. During rounds, the chief in charge, the doctors said 'ma'am' and 'sir,' while scavenging beneath brown skin for carrion. An objective exam, nothing personal. The patient is a poor historian, they groaned. This lacked a cure.

\section{Jack Coulehan MD MPH}

Senior Fellow

- Center for Medical Humanities,

\& Compassionate Care and Bioethics

Stony Brook University

Setauket, USA

Dr. Coulehan's most recent collection of poems is Medicine Stone (Fithian Press; 2002).

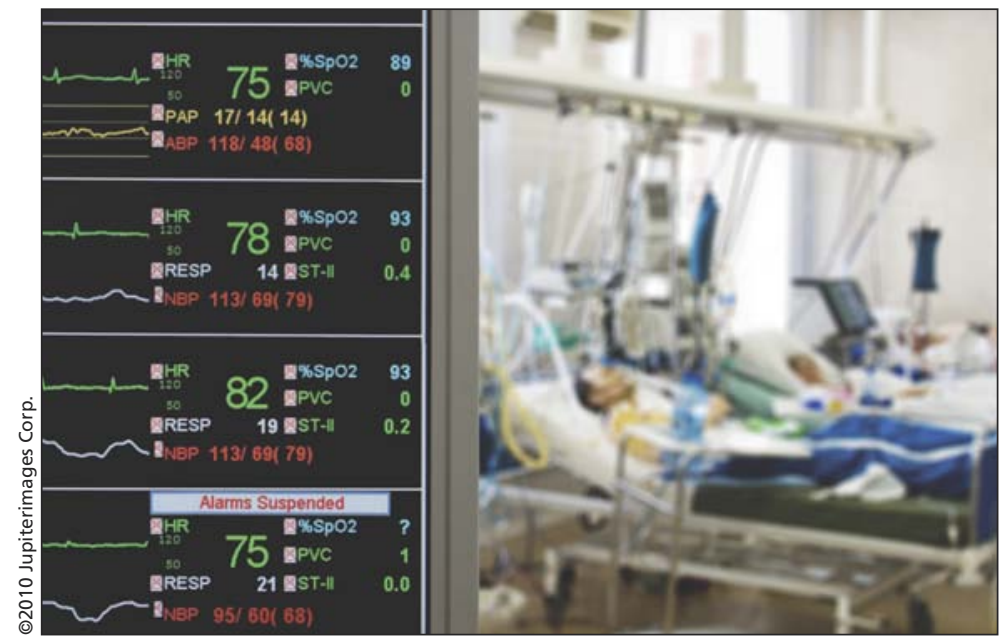

